\title{
Development of Physics Learning Media Using IPRO (Interactive Presentation PowerPoint) Animation on the Global Warming Topic
}

\author{
Alifia Rohimatul A'zizah*, Mita Anggaryani \\ Physics Department, Faculty of Mathematics and Science, Universitas Negeri Surabaya \\ *Email: alifia974@gmail.com
}

DOI: https://doi.org/10.33369/pendipa.5.3.436-443

\begin{abstract}
IPRO is an interactive presentation learning media using PowerPoint as a learning media in the form of an application. The topic used in the learning media is global warming. This media presents material in the form of animation that can build interaction between students and digital media.This research aimed to produce appropriate and effective digital learning media in physics online learning activities on animation-based global warming topic using PowerPoint. The research method used was the development of ADDIE. This study states that the developed IPRO is suitable for studying global warming material with consideration of the validity and effectiveness data results that meet the media category. The data collection technique used a validation questionnaire the results $90.5 \%$ included in the very valid caragory and fit for uses. The effectiveness of high school student learning, which can be proven $87.05 \%$ by the mean percentage of respondents who have met the criteria is very valid. Therefore, the IPRO physics learning media that has been developed is suitable for uses in learning.
\end{abstract}

Keywords: IPRO, Validation, Effectiveness, PowerPoint, Global Warming.

\section{INTRODUCTION}

Education is important to every human being. According to research conducted by Sujana (2019), the functions and objectives of education in Indonesia play a role to create a society of high integrity and a generation of experts and skilled in each study. The potential that can be developed optimally in human beings is the physical, intellectual, emotional, social and spiritual aspects with the stage of development supported by the surrounding environment.

Physics learns about the knowledge of the universe that requires reasoning and the ability to think, to support the evolution and curiosity of students. Physics is difficult by presenting formulas as a vocabulary understanding and it feels boring when studying materials that are comfortable. In increase to the next problem, there are few interesting and motivating learning media in physics subjects. Interesting media and close to students are able to improve the mastery of concepts. Packaging of quality and informative materials supports the strengthening of student understanding With reference to the development of multimedia-based learning media, qualified educators and creativity can provide a treat of student learning motivation increased (Riskiawan, 2016). One of the materials of global warming is an increase in average temperatures on land, oceans and air that results in extreme weather intensity. The selection of global warming materials is considered in accordance with the consideration of the rising concentration of greenhouse gases in the surrounding environment, especially in industrial areas. In increase, farmers receive a decrease in crop yields both quantity and quality of products so as to affect the selling price of the market. From this phenomenon is very concerned for the future of the earth and humans, therefore it is necessary to make changes by studying global warming material to review how the causes and effects of global warming. Along with the individual consciousness of the importance of education and character that cannot be separated from daily life there is also the development of technology and information that can be the best place to channel various information. 
In the development of technology and information in today's digital era has an influence on life in various fields, especially education. Positive development that must be utilized for educators by analyzing the right technology as a teaching medium can assemble the criteria of learning media. This can help online learning activities that are conducted in each student's home during the current pandemic. Online learning is done in each student's home, according to the interests of learning students, but at times like this student and the diamonds must comply with the protocol to take care of each other's health. More innovation and creativity are required in order to increase the quality and quantity of students in learning. Students are considered able to be interested in online learning if done at school or not at home in order to be friends to study sounds group Sundus (2020). Supported by Mustari (2019), the development of digital learning media on global warming materials deserves to be used in the classroom by having an appeal that gets students motivated to learn more quality. The use of digital platforms can be used for every student, but has weaknesses in the limited internet networks that enter into certain areas and not every student has an internet data package (Andi, 2020). The development of IPRO digital technology, media provides solutions to current educational problems by utilizing powerpoints and androids. This media can be accessed without using the internet net so that students can learn quietly without having to think about networking and focus on learning. In addition, it can be accessed at any time when students take part in learning and real learners. With Microsoft PowerPoint which is a software to exhibit information in written form, animation, video or audio. According to certain (2020), learning using animation can improve the representation of students' understanding in understanding learning rather than not using animation as a material delivery tool. Equipped with hyperlink features, and transitions. Everything, there are advantages and disadvantages, PowerPoint have a drawback in accessing done on the Microsoft platform, animations are less interesting and the documents displayed sometimes mess with different versions. Innovation in the utilization of PowerPoint and android applications can help achieve learning targets along with mastery of teachers in usage (Nurhidayati, 2019).

Interactive learning media can improve the understanding of concepts with media that has been validated by experts so as not to cause poisoning in media users. The effectiveness of the media can be known through the positive response of students so that it is suitable to be applied in physics learning materials (Inung, 2018). Android-based interactive media can realize interaction between users and applications just like students in interacting directly with learning media. The advantages with such media can minimize the problem that often occurs is not carrying textbooks while in school or can help self-study at home (Roni, 2020). Based on the description that has been presented, researchers are interested in researching the development of learning media that can help students to understand the material of global warming. Researchers hope this learning medium can build a two-way interaction between students and computers or androids. Researchers hope to improve students' interactive physics learning process, in addition to motivating students to maintain the environment such as the application of global warming materials. According to Yani's research (2020) about the motivation of online learning by reviewing from the aspect of conveying ideas or ideas have five categories one of them with initial capital that is curiosity. The first category can generate high learning spirit and motivation to get a description of the questions presented. The researcher's goal is titled IPRO High School Physics Learning Media Development (Interactive PowerPoint Presentation) Based animation on Global Warming Materials to describe the validity of learning media development and describe the effectiveness of IPRO learning media on global warming materials.

\section{METHOD}

The type of research used is developed (Research and Development) with the ADDIE method (Analysis, Design, Develop, Implementation, Evaluation). 


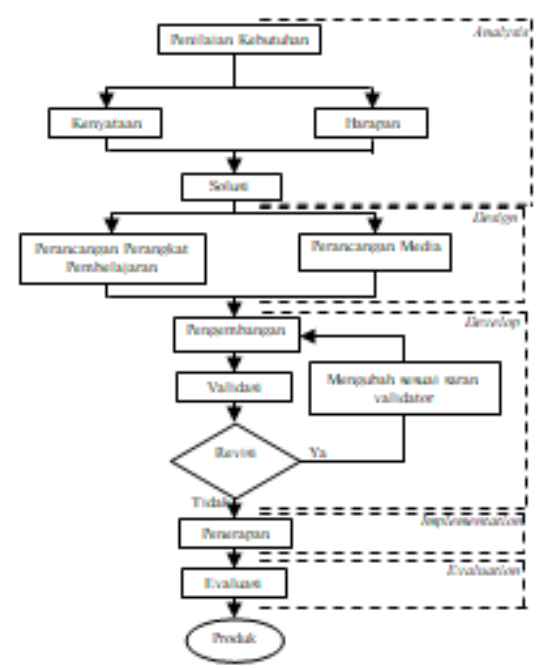

Figure 1. ADDIE metod

The data were collected by using the expert validation method and the student response questionnaire. Validation sheets filled out by experts in the field of media and materials developed to assess the validity of IPRO media. The subjects of this study were two expert lecturers as validates and 35 high school student respondents in Jombang Regency. Qualitative data analysis was carried out through validation sheets and respondents' opinions of media users. The data obtained is based on the validity and effectiveness of IPRO learning media. For this data analysis, processing data from the validation results that have been reviewed by experts. Data from a questionnaire given to all experts, then used descriptive statistical analysis, then obtained using the following formula: (source: modification of Akbar's criteria (2013: 82) $\mathrm{P}(\%)=(\Sigma$ score data collection results $) /($ Criteria score $) \times 100 \%$

Criteria score $=$ highest score $\mathrm{x}$ number of aspects $\mathrm{x}$ number of respondents.

The percentage of the questionnaire data are obtained based on calculations.

Table 1. Description of the assessment

\begin{tabular}{cl}
\hline Score & Valuation \\
\hline 5 & Very Valid/ Very Good \\
4 & Valid/ Good \\
3 & Quite Valid/ Medium \\
2 & Less Valid/ Bad \\
1 & Not Valid/ Very Bad \\
\hline
\end{tabular}

Tabel 2. Based on the criteria for learning media in this study, it is said to meet the criteria if the percentage is $\geq 62 \%$ or in the valid category, so it is suitable for use in the learning process.

\begin{tabular}{cl}
\hline \multicolumn{1}{c}{ Score } & Criteria \\
\hline $81 \%<x \leq 100 \%$ & Very Valid \\
$62 \%<x \leq 81 \%$ & Valid \\
$43 \%<x \leq 62 \%$ & Quite Valid \\
$24 \%<x \leq 43 \%$ & Less Valid \\
$5 \%<x \leq 24 \%$ & Not Valid \\
\hline
\end{tabular}

\section{RESULTS AND DISCUSSION}

The result of this research is a learning media for IPRO application (Interactive powerpoint presetation) to help the learning process and understanding of physics lessons on global warming material. The research method used was ADDIE.

\section{Analysis}

At this initial stage, a learning analysis will be carried out with an online system that is new enough to be implemented in schools with the Indonesian curriculum. Relationship between expectations and facts on the power point learning media for learning Global Warming material. The hope is that during the current pandemic, it will become a new breakthrough in delivering interactive and informative material. At this stage the researcher conducts a literacy study about learning media that can be used both online and offline learning. According to Spardi (2020), that the influence of learning media in fostering student interest in getting effective results and fulfilling student interest. The physics learning process uses media that can arouse interest in learning physics compared to using conventional physics learning. Encouraged by the teacher's creativity in developing media to present material. Besides that, the effect of learning that is daring to be applied today in understanding and motivation to learn physics according to Nurmaulidia (2020), that students cannot understand the material provided by the teacher by connecting that not all students can understand quickly. For that students choose face-to-face physics learning with government 
regulations. It is necessary to develop virtual presentations to assist students in following learning in Yulianti's (2017) research, that learning using PowerPoint can provide contextual closeness in understanding material with innovative, creative and commutative learning media, especially in terms of visual communication For the effectiveness of online learning, it becomes effective if it includes essential components such as discursive, adaptive, interactive and reflective with these components it can build the effectiveness of online learning using technology (Riskey, 2020). Supported by Agus' research (2020), the existence of a virtual room helps students to do e-learning by preparing the term self-directed learning because learning is carried out individually at home. From the results of this literature study, the researcher hopes that the IPRO media can be motivated and effectively used when online learning against the background of the current pandemic.

\section{Design}

At this stage, the design is carried out in the form of material that will be applied to learning media, including:

- Formulation of basic competencies in accordance with the material to be taught with the revised 2013 curriculum.

- Compilation of global warming material in accordance with the indicators that have been made.

- Interactive menu planning on power point learning media.

- Preparation of students' understanding questions.

- Preparation of response questionnaires

\section{Development}

At this stage, the development and improvement of power point learning media is carried out. After the media has been designed, several revision and validation processes are carried out so that there are no errors in the learning media. The variables used in this study are,

a. Control variables are variables that can be controlled. This variable is related to the independent variable and the control variable so that the results of this study can only be influenced by these two variables. The control variable in this study contains global warming material.

b. Independent variables are variables that can be influenced by factors related to research. This variable is related to influencing and causing the dependent variable to emerge. In this study, the independent variables used by respondents in the use of IPRO learning media.

c. The dependent variable is a variable that is influenced by the independent variable. In this study, the independent variables used were the results of the responses of the media experts' instruments. By paying attention to the results of the media validity, the criteria are valid if the percentage is $\geq 61 \%$ or in a good category, so that it is suitable for use in the learning process with display, illustration, language, content and consistency indicators on the media assessed by expert lecturers.

The operational definition of this research is as follows:

a. The validation of this study was reviewed from the power point learning media and global warming learning materials. The validation of this media will be reviewed in terms of media and material in accordance with the indicators that have been designed. Validation is filled in by validators who are experts in their respective fields by filling out the media and material validation instrument sheets.

b. Effectiveness, namely the success of learning media can be applied during the learning process. The effectiveness of this can be seen in the success of IPRO as a media for learning physics with the respondents' assessment of the use of the media.

c. Power Point Learning media is a learning media software that is able to display material in an attractive form and can produce media products in the form of offline.

d. Student is individuals who develop potential in themselves through educational benches in various lessons.

Table 3. Criteria validator assesmen.

\begin{tabular}{l|l|l|l|l}
\hline Rated aspect & \multicolumn{2}{|l|}{$\begin{array}{l}\text { Validator } \\
\text { Assessment }\end{array}$} & $\begin{array}{l}\text { Validity } \\
(\%)\end{array}$ & Criteria \\
\cline { 2 - 3 } & $\mathbf{1}$ & $\mathbf{2}$ & & \\
\hline
\end{tabular}

The conformity of the media with the principles of good instructional media 


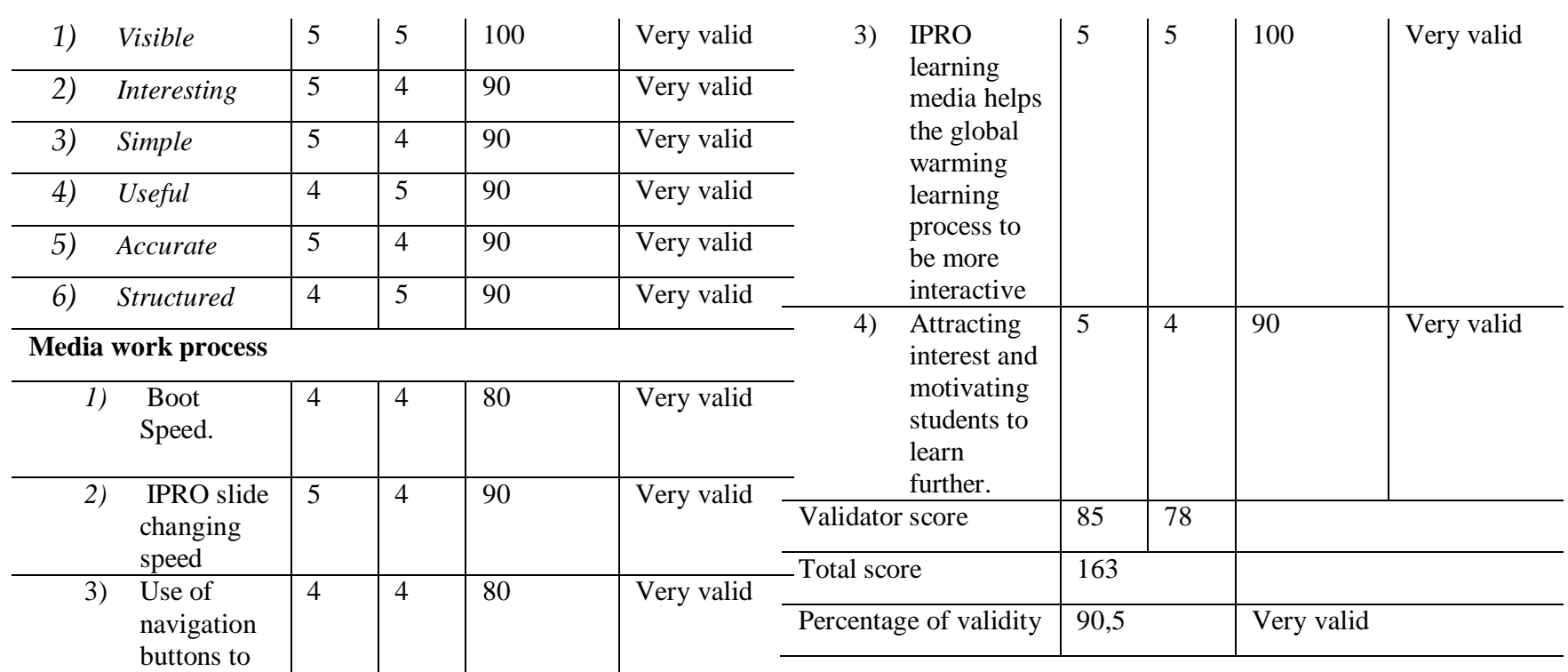

support

ease of use of IPRO

\begin{tabular}{cl|l|l|l|l}
\hline Media display \\
\hline 1) & $\begin{array}{l}\text { Layout } \\
\text { compatibili } \\
\text { ty,font } \\
\text { selection in } \\
\text { IPRO }\end{array}$ & 5 & 4 & 90 & Very valid \\
\hline 2) & $\begin{array}{l}\text { Selection of } \\
\text { Backgroun } \\
\text { d. }\end{array}$ & 5 & 3 & 80 & Very valid \\
\hline 3) & $\begin{array}{l}\text { Color } \\
\text { selection. }\end{array}$ & 5 & 4 & 90 & Very valid \\
\hline 4) & $\begin{array}{l}\text { Animation } \\
\text { Selection. }\end{array}$ & 5 & 4 & 90 & Very valid \\
\hline 5) & $\begin{array}{l}\text { Readability } \\
\text { of Global } \\
\text { Warming } \\
\text { material } \\
\text { information }\end{array}$ & 5 & 5 & 100 & Very valid \\
\hline
\end{tabular}

\section{Global Warming Material}

\begin{tabular}{l|l|l|l|l}
\hline 1) $\begin{array}{l}\text { Compatibili } \\
\text { ty of Basic } \\
\text { Competenc } \\
\text { ies (KD) in } \\
\text { the global } \\
\text { warming } \\
\text { curriculum } \\
\text { 2013 } \\
\text { material }\end{array}$ & 5 & 5 & 100 & Very valid \\
\hline 2) $\begin{array}{l}\text { Helping } \\
\text { students } \\
\text { understand } \\
\text { the } \\
\text { concepts } \\
\text { related to } \\
\text { global } \\
\text { warming } \\
\text { material }\end{array}$ & 4 & 5 & 90 & \\
\hline
\end{tabular}

The development of IPRO physics learning media includes a menu of GLOBAL warming material which is explained in text and audio and is equipped with an animated explanation video in each sub material presented, here is a picture from the main menu:

In the main menu there are several choices, including global warming material which contains the definition of global warming, the causes of global warming, the impact of global warming and also the solution to preventing global warming. In addition, to complete the information, there is also a media developer profile along with instructions for using IPRO media.

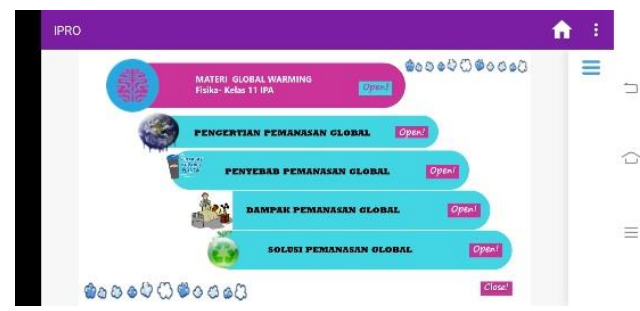

Figure 2. Explanation menu IPRO of global warming.

In the picture above is an explanation of the meaning of the material by using a written explanation accompanied by a picture of the global warming mechanism process in the IPRO media.The picture above is an excerpt from an explanation of global warming in writing and animation with material from natural causes and human interference. Natural causes can be 
viewed through the text presented, in contrast to the causes of human intervention by selecting the icon displayed on this page to find out the cause and further explanation. In addition to text explanations, there are also video and audio animations that are designed to take advantage of the use of animations, transitions and several supporting menus on PowerPoint. The audio contains material that is more concise than written explanations.

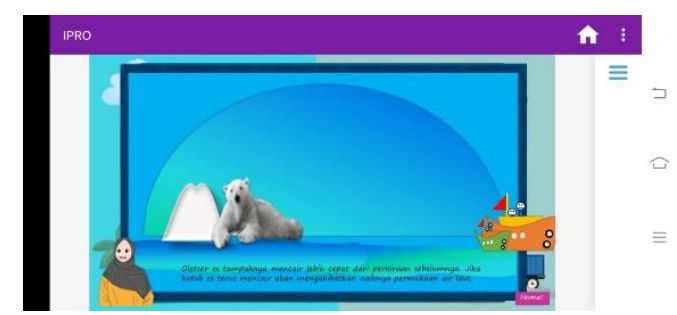

Figure 3. Animation impact of global warming.

This animated snippet shows the impact of global warming which is displayed with an animation along with an audio explanation. The impact of global warming contains material with the contents of melting glaciers, extreme weather accompanied by its effects such as drought and flooding in parts of the world, besides that sea level increases. The real impact on humans is crop failure, the spread of disease for humans. This explanation is expected to help humans understand that global warming has a fatal impact on everyday life.

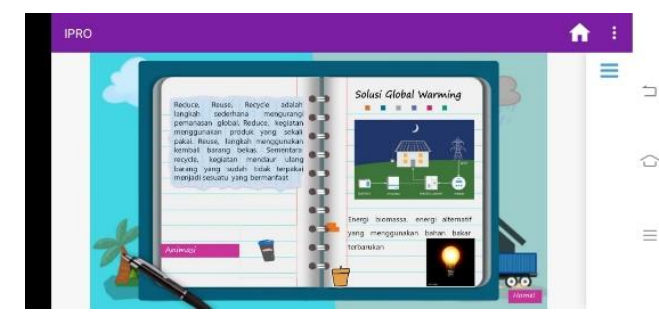

Figure 4. Explanation writing solution of global warming.

In addition, the material presented is a solution to solving the current global warming problem and prevention of subsequent problems. The solution presented is in the form of tree planting efforts, reducing plastic use and doing $3 r$ (Reduce, Reuse, Recycle), use of biomass energy and so on.

\section{Implementation}

In addition, the material presented is a solution to solving the current global warming problem and prevention of subsequent problems. The solution presented is in the form of tree planting efforts, reducing plastic use and doing 3r (Reduce, Reuse, Recycle) and use of biomass energy.

\section{Evaluation}

In the final stage the evaluation is carried out after all the learning media application processes are complete. Evaluation aims to assess the effectiveness of the media being developed. After the implementation stage is carried out, the respondents, totaling 30 students, fill out the response questionnaire sheet which aims to find out the respondents' responses to the developed IPRO learning media. This response questionnaire is to find out the responses of respondents in the field and to find out the advantages and disadvantages of the media in their use according to the respondents' views.

Table 4. Following are the results of the response questionnaire assessment.

\begin{tabular}{|c|c|c|}
\hline Question & $\begin{array}{l}\text { Answer } \\
\text { "YES" }\end{array}$ & $\begin{array}{c}\text { Percentage } \\
(\%)\end{array}$ \\
\hline $\begin{array}{l}\text { Learning using physics } \\
\text { learning media IPRO } \\
\text { SMA (Interactive } \\
\text { Powerpoint } \\
\text { Presentation) based on } \\
\text { animation on } \\
\text { interactive and more } \\
\text { interesting Global } \\
\text { Warming material }\end{array}$ & 28 & 93,3 \\
\hline $\begin{array}{l}\text { Learning media about } \\
\text { Global Warming based } \\
\text { on Power Point is easy } \\
\text { to operate. }\end{array}$ & 27 & 90,0 \\
\hline $\begin{array}{l}\text { The material } \\
\text { information conveyed } \\
\text { through animation and } \\
\text { audio on IPRO media } \\
\text { makes it easier to } \\
\text { understand the concept } \\
\text { of global warming } \\
\text { material }\end{array}$ & 25 & 83,3 \\
\hline $\begin{array}{l}\text { Power Point-based } \\
\text { physics learning media } \\
\text { using the language used } \\
\text { is effective }\end{array}$ & 24 & 80,0 \\
\hline
\end{tabular}




\begin{tabular}{l|l|l} 
& & \\
\hline $\begin{array}{l}\text { I am more interactive in } \\
\text { learning about global } \\
\text { warming. }\end{array}$ & 26 & 86,6 \\
\hline $\begin{array}{l}\text { I better understand the } \\
\text { importance of } \\
\text { protecting the } \\
\text { environment for } \\
\text { preventing global } \\
\text { warming with the } \\
\text { support of animation. }\end{array}$ & 26 & 86,6 \\
\hline $\begin{array}{l}\text { I understand that the } \\
\text { global warming cycle is } \\
\text { very close to daily }\end{array}$ & 27 & \\
activities. & & \\
\hline $\begin{array}{l}\text { I support the one tree } \\
\text { one person movement } \\
\text { and reduce the use of } \\
\text { plastics. }\end{array}$ & 26 & 90,0 \\
\hline Percentage average & 87,05 & \\
\hline
\end{tabular}

Based on the results of the respondent's questionnaire, it can be seen that the average percentage obtained is $87.05 \%$. This shows that the IPRO learning media gets responses which, according to the category of the response questionnaire results, are in the very valid category.

According the results of research on the develompment of learning media IPRO has advantages, namely the results of validation and response questiopnnaires can be used as an attractive and alternative media for online learning and learning evaluation instruments in the form of equastions and link response equestionnaires can be accessed through IPRO media. However, for the shortcomings of IPRO learning of the validation and response equationnaires above lie in the navigation of the directions and the slide background of the learning media which are deemed less attractive. In addition, IPRO media can be said to br suitable for use in learning, especially learning systems whit government policies implementing.

\section{CONCLUSION}

According to the description above, it can be concluded that the validity of an IPRO learning media in the global warming material developed has an average percentage value of $90.5 \%$ which is a very valid category so that it meets the eligibility requirements of the validity aspect of a media. That way this media can be considered feasible to be applied to support the learning process. The effectivenesss of learning media IPRO based on the vlue of student respondents with the value of the percentage value of $87.05 \%$ which is a very valid category.

\section{REFERENCE}

Agus Wilson. (2020). Penerapan Metode Pembelajaran Daring (Online) Melalui Aplikasi Berbasis Android Saat Pandemi Global. Jurnal: Susunan Artikel Pendidikan. 3(1).

Akbar, S. 2013. Instrumen Perangkat Pembelajaran. Bandung: Remaja Rosdakarya Offset

Andi H. F., Restu J ., Ali W R., \& Syawal. (2020). Digital Content For Millennial Generations: Teaching The English Foreign Language Learner On Covid-19 Pandemic. Jurnal of Southwest Jiaotong University, $55(3)$.

Christian S. U., Chinedu I. O. O., Peace A. N., Euphemia C. O. \& Christian C. Obasi. (2020). Relative Effect of Animated and Non-Animated Powerpoint Presentations on Physics Students' Achievement. Cypriot Journal of Educational Science, 15. 282-291.

Inung D. K \& Sekreningsih N. (2018). Media Pembelajaran Berbasis Multimedia Interaktif untuk Meningkatkan Pemahaman Konsep Mahasiswa. Journal of Computer and Information Technology, 1(2), 68-75.

Mustari M., Hoya A.L,, Akmansyah M., Diani R., Asyhari A. (2019). Journal of Physics: Conference Series.

Nurhidayati, Ansrosi I., Ahsanuddin M., \& Wahib D. M. (2019). Pembuatan Media Pembelajaran Berbasis Powerpoint dan Pemanfaatan Aplikasi Android untuk Guru Bahasa Arab. Jurnal Karinov, 2(3). 
Riskiawan H. Y, Dwi P.S.S \& Arifianto A.S. (2016). Pelatian Pengembangan Media Pembelajaran Berbasis Multimedia Untuk Meningkatkan Kualitas dan Kreativitas Guru SMA. Jurnal Pengabdian Masyarakat, 1(1).

Riskey Oktavian, Riantina Fitra Aldya. (2020). Efektivitas Pembelajaran Daring Terintegrasi Di Era Pendidikan 4.0. Jurnal Pendidikan Dan Ilmu Pengetahuan, 20 (2) 130-135.

Romi A., Maulana M. S., \& Arief Y. M. (2020). Aplikasi Interaktif Teknolog Layanan Jaringan Sebagai Media Belajar Siswa Berbasis Android. Kalano: Jurnal of MultiDisciplinary Sciences. 1(1), 34-43.

Sundus N. \& Yoga B. B. (2020). Pengaruh Media Pembelajaran Online Dalam Pemahaman dan Minat Belajar Siswa Pada Konsep Pelajaran Fisika. Jurnal Kajian, Inovasi, dan Aplikasi Pendidikan Fisika, 6(2), 248-251.

Sujana Cong Wayan I. (2019). Fungsi dan Tujuan Pendidikan Indonesia. Jurnal Pendidikan Dasar, 4 (1), 31.
Supardi U.S., Leonard, Huri Suhendri, Rismurdiyati.(2020).Pengaruh Media Pembelajaran Dan Minat Belajar Terhadap Hasil Belajar Fisika. Jurnal Formatif, 2910, 71-81.

Yani, F., Irfan, F.,, \& Mia Z. S.,. (2020). Motivasi Belajar Mahasiswa Pada Pembelajaran Daring Selama Pandemik Covid-19. Jurnal Kependidikan: Jurnal Hasil Penelitian dan Kajian Pustakaan di Bidang Pendidikan, Pengajaran dan Pembelajaran, 6(2), 165-175.

Yulianti, Achmad Buchori, Yanuar Hery Murtianto. (2020). Pengembangan Media Presentasi Visual Dengan Pendekatan Kontekstual Dalam Pembelajaran Matematika Di Smp. Journal Of Mathematics Education, Science And Technology. 2 (2), 231-242. 